\title{
Green Biosynthesis of Spherical Silver Nanoparticles by Using Date Palm (Phoenix Dactylifera) Fruit Extract and Study of Their Antibacterial and Catalytic Activities
}

\author{
Saeed Farhadi, ${ }^{1, *}$ Bahram Ajerloo $^{1}$ and Abdelnassar Mohammadi ${ }^{2}$ \\ ${ }^{1}$ Department of Chemistry, Lorestan University, Khoramabad 68151-44316, Iran \\ ${ }^{2}$ Department of Biology, Lorestan University, Khoramabad 68151-44316, Iran \\ * Corresponding author: E-mail: sfarhadi1348@yahoo.com \\ Tel.: +98-6633120618, fax: +98-6633120611
}

Received: $30-09-2016$

\begin{abstract}
In this work, we have synthesized spherical silver nanoparticles (Ag NPs) by a low-cost, rapid, simple and ecofriendly approach using Date palm fruit extract as a novel natural reducing and stabilizing agent. The product was characterized by UV-visible spectroscopy, X-ray diffraction (XRD), Fourier transform infrared spectroscopy (FTIR), field emission scanning electron microscopy (FESEM), transmission electron microscopy (TEM), atomic force microscopy (AFM), energy-dispersive X-ray (EDX) spectroscopy and Zeta potential measurements. The reaction conditions including time, content of reducing agent and silver nitrate, temperature and $\mathrm{pH}$ were investigated. The optimum yield of Ag NPs was obtained when $10 \mathrm{mM}$ of silver nitrate was reacted with Date fruit extract at $\mathrm{pH} 11$ and heated it to $55^{\circ} \mathrm{C}$ within $10 \mathrm{mi}-$ nutes. The elemental and crystalline nature of Ag NPs were confirmed from EDX and XRD analysis. SEM and TEM images showed that the Ag NPs were spherical and with sizes in the range of $25-60 \mathrm{~nm}$. On the base of FT-IR analysis, it can be stated that the functional groups present in bio-molecules of Date fruits are responsible for the reduction and stabilization of Ag NPs, respectively. The Ag NPs showed good antibacterial activity against a few human pathogenic bacteria. The catalytic activity of the Ag NPs for rapid and efficient reduction of toxic nitro compounds into less toxic corresponding amines by using $\mathrm{NaBH}_{4}$ was also investigated.
\end{abstract}

Keywords: Biosynthesis, Silver nanoparticles, Date palm fruit extract, Antibacterial activity, Nitro reduction, Catalyst

\section{Introduction}

Among various transition metal nanoparticles, silver nanoparticles (Ag NPs) have attracted considerable attention in nanoscience and nanotechnology due to their excellent optical and electronic properties as well as their wide applications in various fields such as catalysis, ${ }^{1}$ surface enhanced Raman scattering, ${ }^{2}$ degradation of environmental pollutants, ${ }^{3}$ biosensors ${ }^{4}$ cancer therapy5 and antibacterial effects. ${ }^{6}$ Several synthetic strategies have been developed for the synthesis of Ag NPs including photochemical, ${ }^{7}$ sonochemical, ${ }^{8}$ sovothermal ${ }^{9}$ and spin coating methods. ${ }^{10}$ Among these, chemical reduction of a silver ions $\left(\mathrm{Ag}^{+}\right)$in presence of a stabilizer is the most frequently applied method for the preparation of Ag NPs as stable colloidal dispersions in water or organic solvents. ${ }^{11}$ The major drawback of chemical method is that the high- ly reactive chemical reductants as well as the stabilizers such as synthetic polymers, surfactants and dendrimers used in this method cause chemical toxicity and serious environmental problems, thus limiting their utility.

In recent years, biosynthesis of metal nanoparticles has received considerable attention due to the growing need to develop clean and nontoxic chemicals, environmentally friendly solvents and renewable materials. ${ }^{12}$ The selection of a non-toxic reducing agent, a cost-effective and easily renewable stabilizing agent and an environmentally benign solvent system are the three main criteria for a greener metal nanoparticles synthesis. In this regard, a great deal of effort has been devoted toward the biosynthesis of silver nanoparticles using bacteria, ${ }^{13-17}$ fungi, ${ }^{18-20}$ actinomycetes, ${ }^{21-23}$ yeast ${ }^{24}$ and viru$\operatorname{ses}^{25-27}$ but the rate of nanoparticle synthesis is faster using fruits and plants extracts than microbes, and the pro- 
duced nanoparticles are more stable. ${ }^{28}$ In recent regards, the synthesis of Ag NPs has been reported by using the natural extract of leaves, seeds and or roots of plants such as Nelumbo nucifera, ${ }^{29}$ Anisochilus carnosus, ${ }^{30} \mathrm{Mi}$ musops elengi, ${ }^{31}$ marine macroalga Chaetomorpha linum, ${ }^{32}$ Bunium persicum, ${ }^{33}$ Olea europaea,${ }^{34}$ Hamamelis virginiana, ${ }^{35}$ Justicia adhatoda ${ }^{36}$ Suaeda acuminata, ${ }^{37}$ Mentha piperita, ${ }^{38}$ Phlomis, ${ }^{39}$ Pennyroyal, ${ }^{40}$ Murraya keenigii,${ }^{41}$ Mangifera indica,${ }^{42}$ Nicotiana tobaccum,${ }^{43}$ Bunium persicum, ${ }^{44}$ Hamamelis virginiana ${ }^{45}$ However, the reaction time of $\mathrm{Ag}^{+}$ions for complete reduction in these works was very long. To enable the biosynthesis methods of Ag NPs to compete with the chemical methods, there is a need to achieve faster synthesis rates with high monodispersion. The use of fruit extracts of plants is an appropriate candidate for this purposes. Several papers on the synthesis of Ag NPs using the extract of fruits such as Terminalia chebula ${ }^{46}$ Solanum trilobatum,${ }^{47}$ Dillenia indica ${ }^{48}$ Solanum lycopersicums, ${ }^{49}$ Tanacetum vulgare, ${ }^{50}$ Crataegus douglasii, ${ }^{51}$ Emblica Officinalis, ${ }^{52}$ and Kiwifruit ${ }^{53}$ have been reported in the literatures.

The Date palm tree (Phoenix dactylifera), a tropical and subtropical tree, is one of mankind's oldest culti- vated plants, and it has played an important role in the day-to-day life of the people for the last 7000 years. ${ }^{54}$ Dates are produced in 35 countries worldwide and cultivated on about 2.9 million acres of land. The world production of date fruit estimate to be more than 7000000 metric tons, and Iran (14\% of world production) is the second major producer after Egypt (17\% of world production). Figure 1 shows the photographs of Date palm trees ant their fruits. The Date fruit is considered to be an inexpensive and easily available important fruit in Iran. ${ }^{55}$ The Date palm fruits are an important source of nutrition, especially in the arid regions where due to the extreme conditions, very few plants can grow. Date fruit also shows some functional properties in the food industry, such as water-holding, oil-holding, emulsifying and gel formation. Indeed, Date fruit can be incorporated in food products to modify textural properties, avoid synthesis and stabilize high fat food and emulsions. ${ }^{56}$ The study by Abdelhak has shown that different varieties of ripe Date fruits contained mainly p-coumaric, ferulic and sinapic acids and some cinnamic acid derivatives. ${ }^{57}$ The in vitro study by Vayalil reported that the aqueous extract of Date fruits has antioxidative and antimutagenic properties. ${ }^{58}$ On the other hand, the study by Bilgari had shown


Figure 1(a)-(d) Photographs of Date palm trees and their fruits. 
a strong correlation between the antioxidant activity and the total phenolic and total flavonoids of palm dates. ${ }^{59}$ The Date fruit is rich in phytochemicals like carbohydrates and sugars, phenolics, sterols, carotenoids, anthocyanins, procyanidins, and flavonoids ${ }^{60}$ Most of the biomolecules can act as reducing and capping agent in the reactions. Then, the Date fruits extract that are inherently rich in these phytochemicals could be used as a novel reducing agent for synthesizing Ag NPs in largescale production.

In this paper, we report on rapid, simple and low-cost synthesis of Ag NPs by the reduction of aqueous $\mathrm{Ag}^{+}$solution using Date fruit extract. To our knowledge, this is the first report on the use of Date fruit for the rapid synthesis of Ag NPs. The nearly monodisperse Ag were formed under mild conditions, without any additive protecting nanoparticles. The formation of Ag NPs was recorded by the UV-visible spectra. Additionally, the obtained Ag NPs were analyzed by Fourier transform infrared (FT-IR) spectra, and X-ray diffraction (XRD), scanning electron microscopy (SEM), transmission electron microscopy (TEM), and energy-dispersive X-ray (EDX) spectroscopy. The rapid approach using Date fruit extract would be suitable for developing a biological process for large-scale production. Various parameters (e.g. concentration of the reactants, reaction temperature, $\mathrm{pH}$ and time) were optimized that would increase the yield of nanoparticle synthesis. The antibacterial and catalytic activities of the biologically synthesized Ag NPs were also investigated.

\section{Experimental}

\section{1. Materials}

Silver nitrate $\left(\mathrm{AgNO}_{3}\right), \mathrm{NaBH}_{4}$, 4-nitrophenol, and 4-nitroanilin were obtained from Merck and were of analytical grade. Double distilled de-ionized water was used for the experiments. All glass wares were properly washed with distilled water and dried in oven.

\section{2. Preparation of Date Palm Fruit Extract}

Date Palm fruit extract was used as a reducing and stabilizing agent for the synthesis of Ag NPs. Date palm fruits were purchased from local supermarket in Iran and used for the synthesis of silver nanoparticles. The fresh fruits of Date washed repeatedly with distilled water to remove the dust and organic impurities present in it. About $15 \mathrm{~g}$ of fruit were crushed into fine pieces with sterilized knife. The fruit of Date Palm were taken into the $250 \mathrm{ml}$ beaker containing $100 \mathrm{~mL}$ double distilled de-ionized water and then the solution was stirred for $30 \mathrm{~min}$ and filtered through Whatman No.1 filter paper twice. The obtained light yellow extract was stored in refrigerator at $4{ }^{\circ} \mathrm{C}$. The extract is used as reducing agent as well as stabilizing agent.

\section{3. Synthesis of Ag Nanoparticles}

In a typical experiment, $\mathrm{Ag}$ NPs were prepared by using Date fruit extract as follows: in a $50 \mathrm{~mL}$ round-bottom flask equipped with a magnet bar, $3 \mathrm{ml}$ of aqueous solution of Date fruit extract was mixed with $20 \mathrm{ml}$ of $10 \mathrm{~m}$ $\mathrm{M}$ aqueous silver nitrate solution. The mixture was then heated at $55^{\circ} \mathrm{C}$ under constant stirring for an appropriate time (e.g. $10 \mathrm{~min}$ ) in an oil bath. The formation process and the optical properties of the silver nanoparticles were identified from both the color change and UV-Vis spectra of the solution. In order to remove the Ag NPs product, the solution was centrifuged at $5500 \mathrm{rpm}$ for $20 \mathrm{~min}$. The supernatant was decanted and the precipitate was re-dispersed in double distilled water for another round of centrifugation. The precipitate was then washed with deionized water for three times to remove any impurities if any. Finally, the washed precipitate was dried in an oven maintained at $60{ }^{\circ} \mathrm{C}$ for $2 \mathrm{~h}$ and finally ground into powder for characterization.

In a similar manner described above, a series of experiments were conducted to investigate the effect of various parameters including reaction time, $\mathrm{Ag}^{+}$ion concentration, the Date fruit extract amount, $\mathrm{pH}$ and temperature on the reaction. The reaction mixtures were monitored by a UV-Vis spectrophotometer at different time intervals and the Ag NPs were characterized further. The effect of $\mathrm{pH}$ on the Ag NPs synthesis was determined by adjusting the $\mathrm{pH}$ of the reaction mixtures $(10 \mathrm{mM}$ silver nitrate, 3 $\mathrm{mL}$ date extract) to $3,5,7,9,11$ or 13 by using $0.1 \mathrm{M} \mathrm{HCl}$ or $\mathrm{NaOH}$ aqueous solutions. The effect of the silver salt was determined by varying the concentration of silver nitrate $(0.1,1,10$ and $100 \mathrm{mM})$. The Date fruit extract content was varied to $1,3,5,7,9 \mathrm{~mL}$, while keeping the silver nitrate concentration at a level of $10 \mathrm{mM}$. To study the effect of temperature on nanoparticle synthesis, reaction mixtures containing $3 \mathrm{~mL}$ Date extract, and $10 \mathrm{mM} \mathrm{Ag-}$ $\mathrm{NO}_{3}$ at $\mathrm{pH} 11$ were incubated at $25,40,55$ or $70{ }^{\circ} \mathrm{C}$.

\section{4. Methods of Characterization}

The UV-visible absorption spectra of Ag NPs colloidal solutions were recorded on a double beam UV-visible spectrometer (Cary 100, VARIAN) operated at a resolution of $2 \mathrm{~nm}$ with quartz cells with path length of $1 \mathrm{~cm}$ in 300-800 nm range. Blanks were prepared with deionized (DI) water. Infrared spectra were obtained using a FT-IR 160 Schimadzu Fourier transform infrared spectrophotometer using $\mathrm{KBr}$ pellets. The XRD pattern of the silver nanoparticles was obtained on an X-ray diffractomer (PANalytical/X'Pert Pro MPD) using $\mathrm{Cu} \mathrm{K} \alpha(1.54059 \AA)$ radiation. The particle size and shape was confirmed using a scanning electron microscope (MIRA3 TESCAN) equipped with EDX attachment. Transmission electron microscopy (TEM) observations were conducted on a Philips CM120 microscope at the accelerating voltage of $200 \mathrm{kV}$. AFM images were recorded on a multi-mode ato- 
mic force microscopy (ARA-AFM, model Full Plus, ARA Research Co., Iran). The surface charge of samples was measured with Zeta potential measurements in water (NICOMP 380ZLS Zeta potential/Particle sizer). Magnetic measurements were carried out at room temperature using a vibrating sample magnetometer (VSM, Magnetic Daneshpajoh Kashan Co., Iran) with a maximum magnetic field of $10 \mathrm{kOe}$.

\section{5. Antibacterial Tests}

Antibacterial activity of the biosynthesized Ag NPs was evaluated against strains of Gram-positive bacteria: Bacillus cereus (PTCC 1015), Staphylococcus aureus (1431) and Staphylococcus epidermidis (PTCC 1114), Gram-negative bacteria: Escherichia coli (PTCC 1330) and Klebsiella pneumonia (PTCC 1290) by modified Kirby-Bauer disk diffusion method [66]. Bacteria were cultured for $18 \mathrm{~h}$ at $37{ }^{\circ} \mathrm{C}$ in Nutrient agar medium and then adjusted with sterile saline to a concentration of $2 \times$ $10^{6} \mathrm{cfu} / \mathrm{mL}$. Bacterial suspension in Petri dishes $(8 \mathrm{~cm})$ containing sterile Mueller-Hinton agar (MA) were cultured using a sterile cotton swab. The compounds were dissolved in water and sterile paper discs of $6 \mathrm{~mm}$ thickness were saturated with $30 \mu \mathrm{l}$ of silver nanoparticles and then placed onto agar plates which had previously been inoculated with the tested microorganisms. Amikacin (30 $\mu \mathrm{g} / \mathrm{disk})$ for gram negative and penicillin for gram positive $(10 \mu \mathrm{g} / \mathrm{disk})$ was used as positive controls. After incubation at $37{ }^{\circ} \mathrm{C}$ for $24 \mathrm{~h}$, the diameter of inhibition zone was measured. The diameter of such zones of inhibition was measured using a meter ruler, and the mean value for each organism was recorded and expressed in millimetres.

\section{6. Catalytic Tests}

In order to study the catalytic performance of the biosynthesized Ag NPs, the reduction of 4-nitrophenol (4$\mathrm{NP})$ to 4-amiophenol (4-AP) by excess sodium borohydride $\left(\mathrm{NaBH}_{4}\right)$ in aqueous solution was used as the model reaction. In a typical catalytic reaction, $3 \mathrm{~mL}$ of aqueous solution of 4-NP $(0.1 \mathrm{mM})$ and $0.5 \mathrm{~mL}$ of aqueous $\mathrm{NaBH}_{4}$ $(10 \mathrm{mM})$ solution were mixed together in a standard quartz cell, having $1 \mathrm{~cm}$ path length and then $1 \mathrm{~mL}$ of aqueous $\mathrm{Ag}$ suspensions $\left(0.5 \mathrm{mg} \mathrm{mL}^{-1}\right)$ was added to the reaction mixture under constant magnetic stirring. Immediately after that, the solution was transferred to a standard quartz cell, and the concentration of p-nitrophenol in the reaction mixture was monitored by the UV-visible absorption spectra recorded with a time interval of $2 \mathrm{~min}$ in a scanning range of $200-800 \mathrm{~nm}$ at ambient temperature. For recycling experiment, after completion of the reaction the catalyst was recovered by centrifugation. The precipitate was washed repeatedly with deionized water in consecutive washing cycles. Ultrasonic treatment was used in every cycle in order to re-disperse the catalyst and remove adsorbed impurities. After washing, the catalyst was used directly for recycling test. After each recycle, the centrifuge supernatant was collected and detected by Atomic absorption spectroscopy to determine the content of Ag metal. The reduction 4-nitroaniline was also investigated under the same conditions.

\section{Results and Discussion}

\section{1. Phytoreduction of Silver Ions}

A study on phytosynthesis of Ag NPs by the aqueous fruit extract of date was carried out in this work. During the visual observation, silver nitrate treated with date fruit extract showed a color change from yellow to brown within 20 min whereas no color change could be observed in silver nitrate solution without date extract (Figure 2). The appearance of yellowish brown color in fruit extract treated flask is a clear indication for the formation of $\mathrm{Ag}$ NPs. This color arises due to excitation of surface plasmon resonance (SPR) vibrations in Ag nanoparticles.

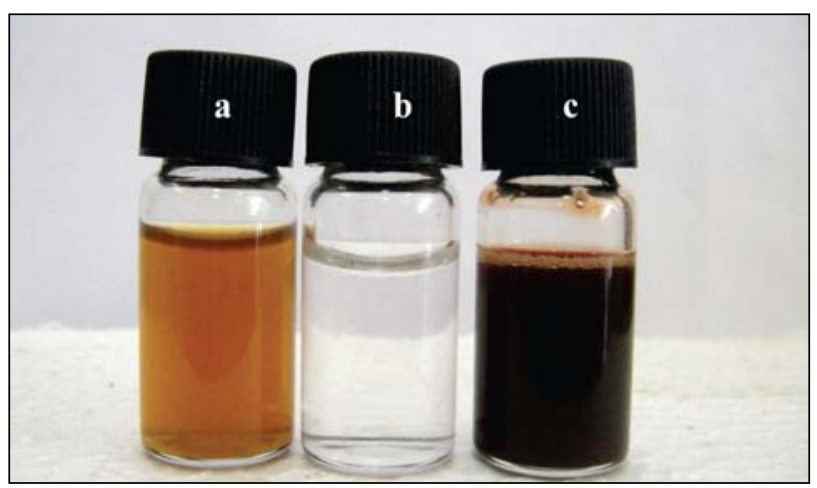

Figure 2. Photographs of: (a) aqueous extract of date fruits, (b) 10 $\mathrm{mM}$ of aqueous $\mathrm{AgNO}_{3}$ solutions, and (c) Colloidal aqueous $\mathrm{Ag}$ NPs solution formed by reduction of $\mathrm{AgNO}_{3}$ with Date fruit extract.

\section{2. UV-Visible Absorption Studies}

$\mathrm{UV}-\mathrm{Vis}$ spectroscopy is a powerful tool to study the formation of Ag NPs. The reaction mixtures containing silver salt and Date fruit extract were, therefore characterized by UV-Visible spectroscopy. Based on $\mathrm{UV}-\mathrm{Vis}$ spectroscopy various chemical and physico-parameters (concentration of the fruit extract and silver salt, $\mathrm{pH}$, temperature and reaction time) were optimized for the reduction $\mathrm{Ag}+$ ions to $\mathrm{Ag}$ NPs using Date fruit extract.

To optimize the reaction time, a time variation study was carried out using the concentration of $\mathrm{AgNO}_{3}(10 \mathrm{~m}-$ M) and aqueous date extract $(3 \mathrm{~mL})$. Figure 3(a) shows the UV-Vis absorption spectra of Ag NPs synthesized at 
different time durations. It is observed that the intensity of SPR bands increases as the reaction time progresses and within 10 min a considerable intensity of the SPR bands is achieved. However, these values were hardly changed after $10 \mathrm{~min}$. It suggested that the reduction time of $\mathrm{Ag}^{+}$was almost completed within $10 \mathrm{~min}$ in the presence of date extract. Therefore, the optimal reaction time for the reduction $\mathrm{Ag}^{+}$ions to $\mathrm{Ag}$ NPs using Date fruit extract is $10 \mathrm{~min}$. As shown in the inset of Fig. 3(a), after the reaction between $\mathrm{Ag}^{+}$and date extract, the color was changed from clear yellow to dark brown and it shows the formation of Ag NPs.

Next, various concentrations of silver nitrate solution $(0.1-100 \mathrm{mM})$ were reacted with $3 \mathrm{~mL}$ fruit extract. Figure 3(b), shows the UV-Vis absorption spectra of $\mathrm{Ag}$ NPs obtained at different concentrations of $\mathrm{AgNO}_{3}(0.1,1$, 10 and $100 \mathrm{mM}$ ). At $0.1 \mathrm{mM}$ concentration, an observable SPR band was not appeared, indicating very low yield of Ag NPs formed (Figure 3(b), curve i), but with increasing concentration of $\mathrm{AgNO}_{3}$ to $1 \mathrm{mM}$, the SPR of Ag NPs appears at $395 \mathrm{~nm}$ and remarkably increases with the increase of $\mathrm{AgNO}_{3}$ concentration to $10 \mathrm{mM}$ with increasing in the peak wavelength to $410 \mathrm{~nm}$ (Figure 3(b), curves i and ii, respectively). High intensity of the $410 \mathrm{~nm}$ SPR band indicates increasing concentration of nanoparticle. However, further increasing the concentration of $\mathrm{AgNO}_{3}$ from 10 to $100 \mathrm{mM}$ did not increase the SPR band further-in contrast, it give a broad SPR band with decreased intensity and shifted to longer wavelength region $(\sim 425 \mathrm{~nm})$. This phenomenon may be due to the fast growth of the particles at high concentration. The appearance of red shifted band at higher concentration of $\mathrm{AgNO}_{3}$ suggests the formation of larger particles. The yield of Ag NPs increased with the increase in silver nitrate concentration $(0.1-10 \mathrm{mM})$ and maximum yield was obtained with 10 $\mathrm{mM}$, and this concentration was selected for further studies.

Additionally, the effect of the date extract amount on the synthesis of Ag NPs was investigated under the provided reaction conditions, and the results are shown in Figure 3(c). As observed, with increasing the date extract quantity from 1 to $3 \mathrm{~mL}$ in $20 \mathrm{~mL}$ of $10 \mathrm{mM} \mathrm{Ag}^{+}$ion solution, the intensity of characteristic SPR absorption bands for Ag NPs increases (Figure 3(c), curves i and ii) and then decreases when the date extract increases further (Figure 3(c), curves iii-v). The maximum absorption was found at a concentration of $3 \mathrm{~mL}$ fruit extract. From the UV-Vis absorption spectrum in Figure 3(c), it was observed that there is a shift in wavelength from 400 to $412 \mathrm{~nm}$ indicating a redshift with increase in date extract concentration from 1 to $3 \mathrm{~mL}$. Accordingly, it can be concluded that with the increase in Date extract amount, the size of Ag nanoparticles increases.

The temperature also affected the process of silver reduction. The effect of reaction temperature was also evaluated with varying reaction temperatures from 25 to
$75{ }^{\circ} \mathrm{C}$ (Figure 3(d)). As shown in Figure 3(d) (curves i and ii), the reaction mixtures incubated at room temperature $\left(25^{\circ} \mathrm{C}\right)$ and $40{ }^{\circ} \mathrm{C}$ showed less pronounced SPR peaks during a long time of $50 \mathrm{~min}$ while by heating the reaction mixtures at 55 and $70{ }^{\circ} \mathrm{C}$ the reduction process was faster and the intense peaks were developed within a short time of 10 min (Figure 3(d), curves iii and iv). This indicates that higher temperature facilitates the formation of Ag NPs due to the increase in the reaction rate. The maximum SPR peak intensity was detected at $70{ }^{\circ} \mathrm{C}$. However, a slight increase in SPR band intensity occurs at $75^{\circ} \mathrm{C}$ when compared with the temperature of $55{ }^{\circ} \mathrm{C}$. Then, the temperature of $55^{\circ} \mathrm{C}$ is preferred for further study. It is noteworthy to mention that with the increase in reaction temperature, UV-Vis spectra show sharp narrow peaks at lower wavelength regions $(\sim 412$ $\mathrm{nm}$ at 55 and $70{ }^{\circ} \mathrm{C}$ ), which indicate the formation of smaller nanoparticles, whereas, at lower reaction temperature, the peaks observed at higher wavelength region $\left(425 \mathrm{~nm}\right.$ at $\left.25^{\circ} \mathrm{C}\right)$ which clearly indicates increase in silver nanoparticles size. It is a well-known fact that when the temperature is increased, the reactants are consumed rapidly leading to the formation of smaller nanoparticles [61, 62].

Among the various parameters, the initial $\mathrm{pH}$ of solution plays a significant role in the synthesis of metal nanoparticle. Thus, in the present study, the effect of $\mathrm{pH}$ on the synthesis of Ag NPs was studied at acidic, natural and basic values using $3 \mathrm{ml}$ Date fruit extract and $10 \mathrm{mM} \mathrm{Ag-}$ $\mathrm{NO}_{3}$. As can be seen in Figure 3(e) (curves i and ii) the formation of $\mathrm{Ag}$ nanoparticles was not observed at all at acidic pHs 3 and 5. Under the acidic conditions, biomolecules are likely to be inactivated. This suggests that acidic $\mathrm{pH}$ is not favorable for the Ag NPs synthesis. At $\mathrm{pH} 7$, the Ag NPs formation was observed at relatively low concentration, as confirmed by the appearance of a weak absorbance band at about $425 \mathrm{~nm}$ (Figure 3(e), curve iii). However, Ag NPs were readily obtained at $\mathrm{pH}$ higher than 7 , as evidenced through progressive evolution of the characteristic SPR band in the spectral region from 400 to 415 $\mathrm{nm}$. As can be seen in Figure 3(e) (curves iv-vi), the intensity of the SPR band of these Ag NPs increased significantly upon increasing the $\mathrm{pH}$ to 9,11 and then 13 , indicating that correspondingly higher yields of Ag NPs were obtained, probably due to the presence of a considerable number of reactive functional groups to bind with silver ions. In addition, a slight red shift of the SPR band of the Ag NPs (from 400 to $415 \mathrm{~nm}$ ) occurred upon increasing the $\mathrm{pH}$. These results suggest that larger-diameter Ag NPs were obtained at higher $\mathrm{pHs}$. The optimal $\mathrm{pH}$ for nanoparticle synthesis was chosen to be $\mathrm{pH} \mathrm{11,} \mathrm{which} \mathrm{is} \mathrm{in} \mathrm{good}$ agreement with the reported literature. ${ }^{63}$ The differences in the amount of Ag NPs obtained over the range of $\mathrm{pH}$ could be ascribed to a variation in the dissociation constants (pKa) of functional groups $(\mathrm{OH}$ and $\mathrm{COOH})$ on the biomolecules that are involved. ${ }^{64}$ 



Figure 3. Effect of various parameters on the synthesis of Ag NPs: (a) The effect of reaction time; The inset photo shows the color change of solution with time of reaction, (b) The effect of $\mathrm{Ag}+$ Concentration; The inset photo shows the color change of solution at different concentrations of $\mathrm{AgNO}_{3}$, (c) The effect of different amounts of Date fruit extract, (d) the effect of different temperatures and (e) the effect of $\mathrm{pH}$.

\section{3. XRD Analysis}

Figure 4 shows the XRD pattern of Ag NPs synthesized using Date fruit extract after the complete reduction of $\mathrm{Ag}^{+}$to $\mathrm{Ag}$ under the optimized conditions $(10 \mathrm{mM} \mathrm{Ag}-$ $\mathrm{NO}_{3}, 3 \mathrm{~mL}$ Date extract, $\mathrm{pH} 11$ at $55{ }^{\circ} \mathrm{C}$ for $10 \mathrm{~min}$ ). As observed in the XRD pattern, the four characteristic diffraction peaks at $2 \theta$ values of $38.10^{\circ}, 44.15^{\circ}, 64.67^{\circ}$, and $77.54^{\circ}$ can be indexed to the (111), (200), (220), and (311) reflection planes of faced center cubic (fcc) structure of silver (JCPDS card no 04.0784). The considerable broadening of the diffraction peaks demonstrates the nanometer nature of the Ag particles. The average crystallite size of the $\mathrm{Ag}$ product is approximately $39.5 \mathrm{~nm}$ as estimated by the Debye-Scherrer equation: $D_{\mathrm{XRD}}=0.9 \lambda /(\beta \cos \theta)$, where $D_{\mathrm{XRD}}$ is the average crystallite size, $\lambda$ is the wavelength of $\mathrm{Cu} \mathrm{K} \alpha$ radiation, $\beta$ is the corrected full-width at half-maximum of the main diffraction peak of (111), and $\theta$ is the Bragg angle. The XRD pattern obtained is consistent with earlier reports. ${ }^{65,66}$ 


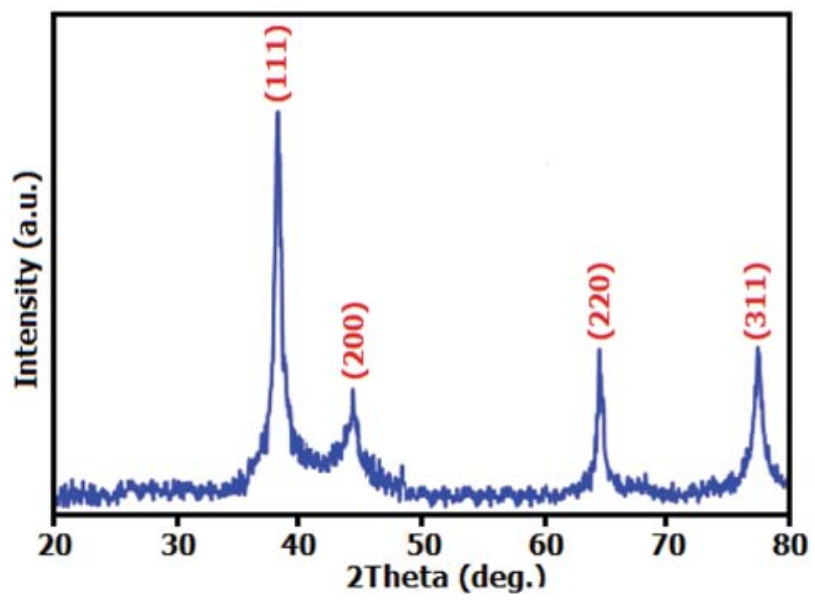

Figure 4. XRD pattern of Ag NPs synthesized by Date fruit extract.

\section{4. SEM, TEM and EDX Analysis}

The size and morphology of the Ag NPs were determined via SEM, TEM and AFM images. Figure 5 shows the SEM images of the as-prepared Ag NPs. From the SEM images in different magnifications (Figure 5(a)-(c)), it is clearly evident that the product consists of extremely fine particles with sphere-like morphologies that appreciably aggregated as clusters due to the extremely small dimensions and high surface energy of the obtained nanoparticles. We also can find from the images that the morphology of the particles is almost homogeneous. The resulting images show the presence of large number of spherical nanoparticles with an average particle size of $42.5 \mathrm{~nm}$. The EDX was used to further characterize the composition of the sample. Figure 5(d) shows the EDX spectrum of the Ag NPs prepared by using Date
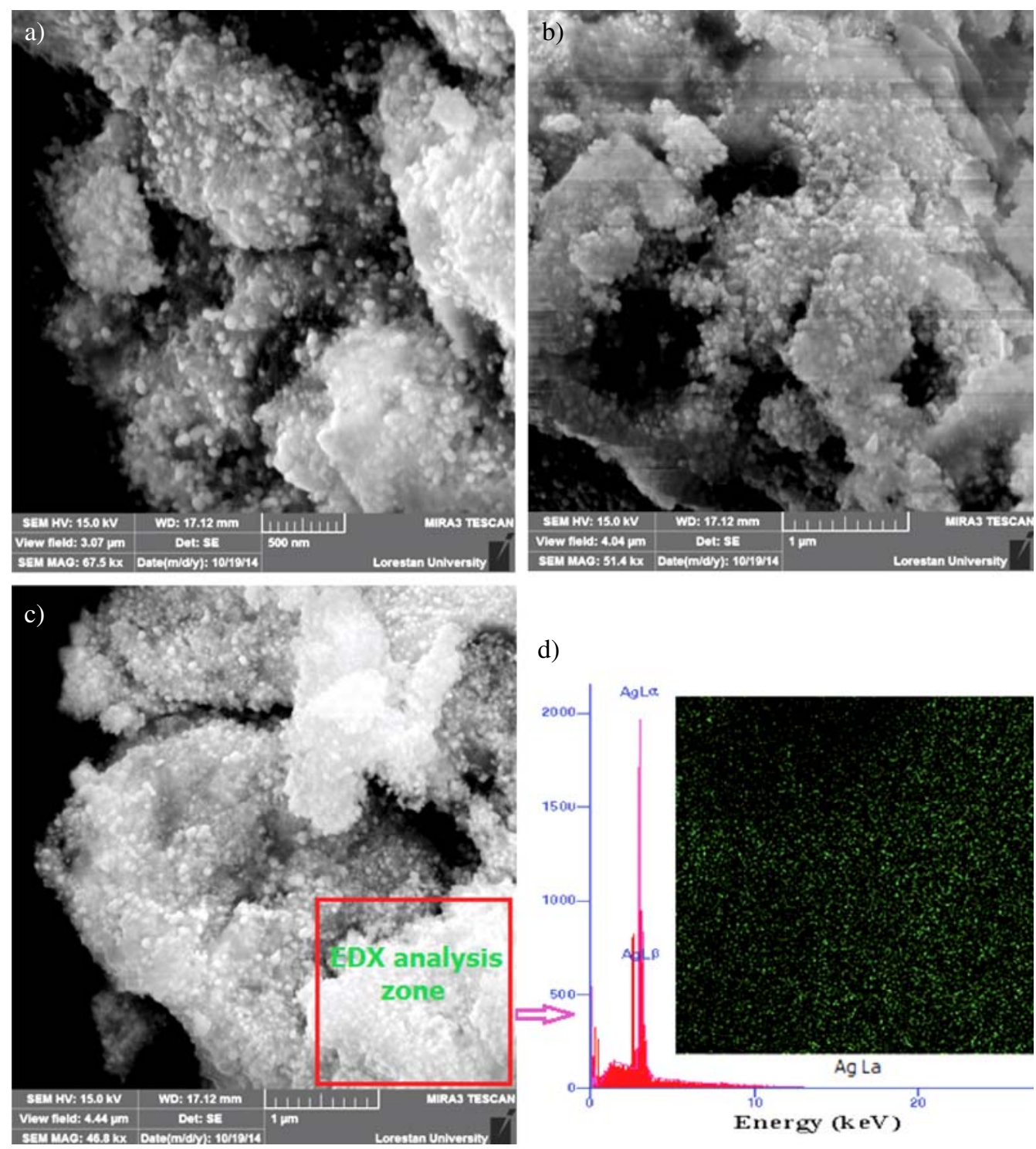

d)

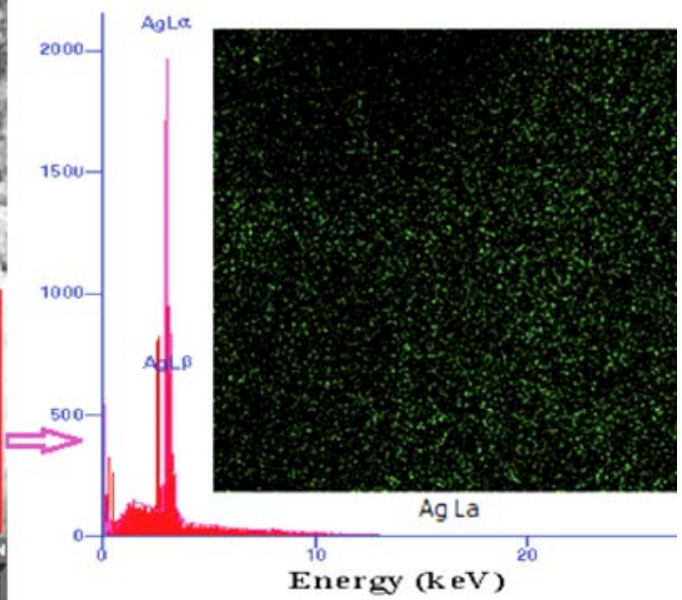

Figure 5. (a-c ) SEM images of the as-prepared Ag NPs, (d) EDX elemental spectrum of the Ag NPs. The inset of Figure 5(d) shows EDX elemental mapping for Ag NPs. 
fruit extract as reducing agent. The intense peaks around $3.40 \mathrm{keV}$ and $3.45 \mathrm{keV}$ are correspond to the binding energies of $A g \mathrm{~K}_{\mathrm{L} \alpha}$ and $\mathrm{Ag} \mathrm{K}_{\mathrm{L} \beta}$, respectively, while the peaks situated blow $0.5 \mathrm{keV}$ corresponding of $\mathrm{N}, \mathrm{C}$ and $\mathrm{O}$ from Date fruit extract. Further, the EDX elemental mapping of the product in the inset of Figure 5(d) displays the uniform distribution of the Ag element. The results further indicate that the Ag NPs have been successfully prepared in this work.

The TEM image and size distribution of the Ag NPs are shown in Figure 6. The TEM sample was prepared by dispersing the powder in ethanol by ultrasonic vibration. It can be seen from Figure 6 that the nanoparticles show approximately sphere-like morphologies with a uniform size. Because of the small dimensions and high surface energy of the particles, it is easy for them to aggregate. We also can find from this figure that the morphology of the particles is almost homogeneous. To investigate the size distribution of the Ag NPs, the particle size histogram was also determined from the TEM image. The inset of Figure 6 shows the size distribution of the Ag particles. It is clear that the diameter sizes of the Ag NPs are in the range of 25 to $60 \mathrm{~nm}$ with a narrow size distribution. The average particle size is approximately $40 \mathrm{~nm}$, which is in agreement with the result calculated for the half-width of diffraction peaks using the Scherrer's formula, allowing for experimental error.

AFM is a beneficial tool for studying various morphological features and parameters. Since, it has the advantage of probing in deep insights of surface topography qualitatively due to its both lateral and vertical nanometer scale spatial resolution. The AFM images in Figure 7 display the surface morphology of the Ag-NPs formed by Date fruit extract. As observed in Figure 7(a), AFM image



Figure 6. TEM image of the Ag NPs. The inset shows the size distribution of the Ag NPs.

reveals the appearance of spherical nanoparticles and their respective particle size and morphology clearly were close to those determined by the SEM and TEM images. As can be seen from Figure 7(b), the surface of Ag NPs sho-
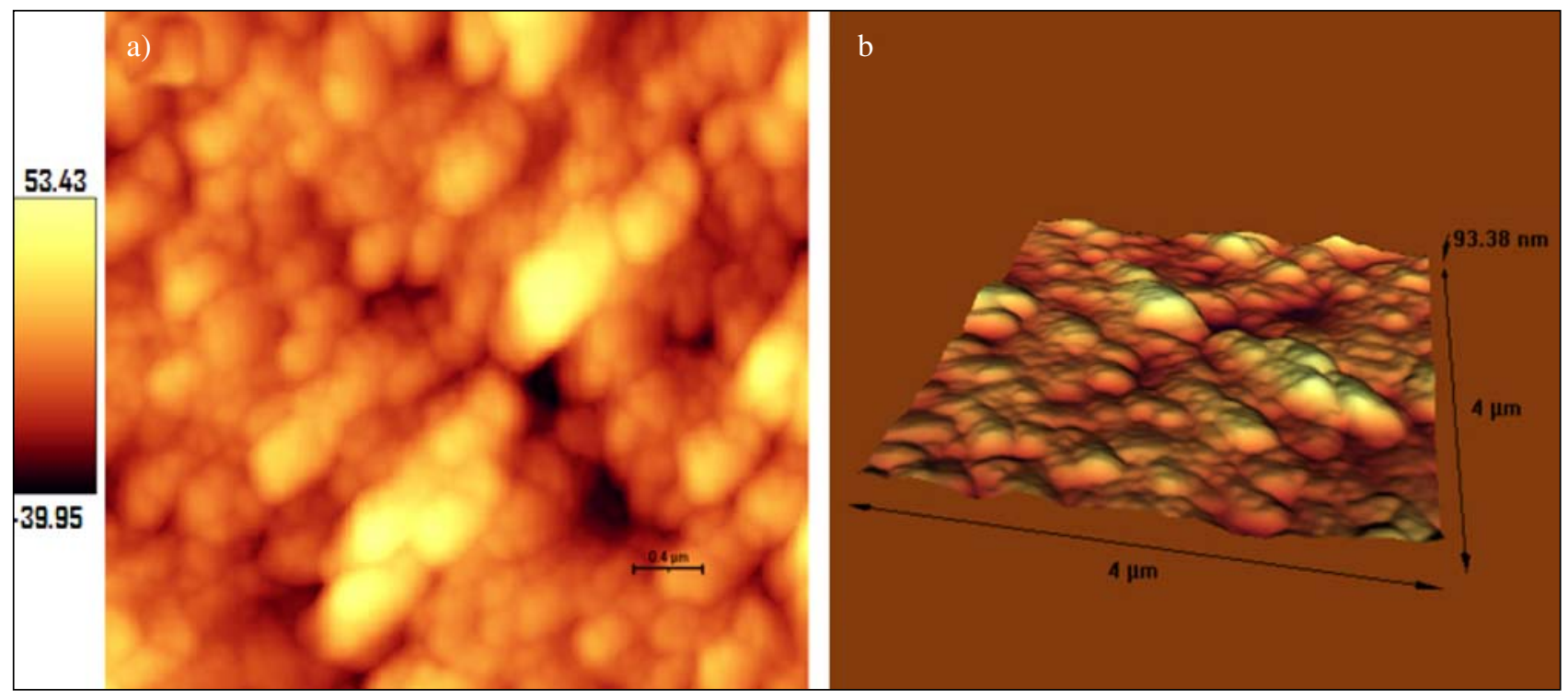

Figure 7. (a) and (b) AFM images of the Ag NPs. 
wed a dense and uniform packed structure. Thus, the $\mathrm{Ag}$ NPs could provide a biocompatible and rough surface for biological uses, e.g., cell immobilization.

\section{5. Zeta Potential Measurements}

Zeta potential provides the information about the stability of nanoparticles and surface charge. Zeta potential is an essential parameter for characterization of stabi-

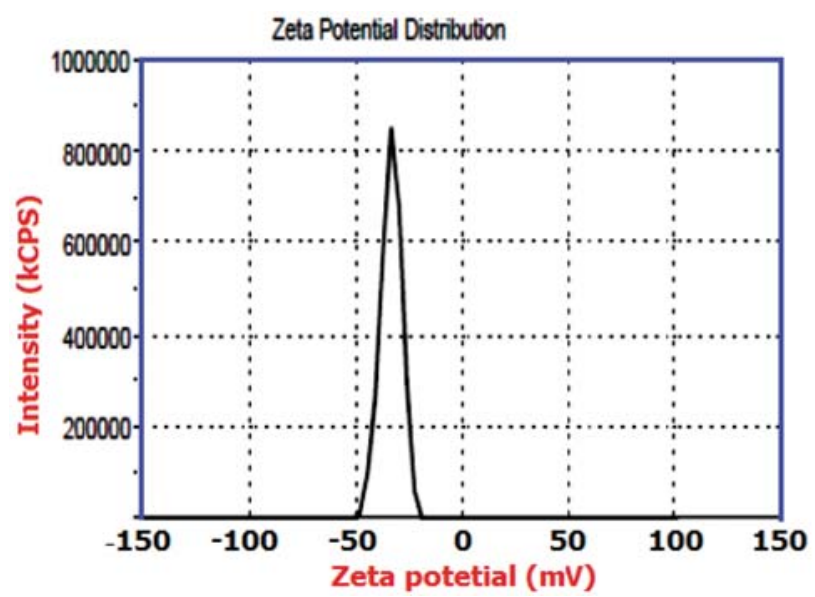

Figure 8. Zeta potential analysis of colloidal Ag NPs solution prepared with Date fruit extract. lity in aqueous colloidal Ag-NPs suspensions. Zeta potential of the synthesized Ag NPs is pictured in Figure 8. The zeta potential value was measured to be about $-35 \mathrm{mV}$ which confirms the good stability of the colloidal Ag NPs aqueous suspension formed by reduction of $\mathrm{AgNO}_{3}$ with Date fruit extract ${ }^{67}$ The high negative values illustrate the repulsion between the particles and thereby attainment of better stability of Ag NPs formation avoiding agglomeration in aqueous solutions.

\section{6. FT-IR Chemical Analysis}

The identification of the possible biomolecules responsible for the reduction and the stabilization of biosynthesized Ag NPs can be achieved by the FTIR studies. It has been reported that the Date palm fruit is rich in phytochemicals like carbohydrates (mainly glucose, sucrose and fructose), phenolic acids, sterols, carotenoids, anthocyanins, procyanidins and flavonoids. ${ }^{60} \mathrm{Fi}-$ gure 9(A) shows the structures of some phytochemicals present in Date fruits As can be seen, these components are containing carboxyl $(-\mathrm{COOH})$, phenolic $-\mathrm{OH}$ and carbonyl $(\mathrm{C}=\mathrm{O})$ functional groups. Figure $9(\mathrm{~B})$ shows FT-IR spectra recorded for the Date fruit extract and the $\mathrm{Ag}$ NPs synthesized with the Date extract before and after washing. The FT-IR spectrum of Date extract in Figure 9(B) (spectrum a) shows phenolic $\mathrm{O}-\mathrm{H}, \mathrm{C}=\mathrm{O}$, and a)<smiles>[R2]C1([R2])Cc2c(O)cc(O)cc2O[C@H]1c1ccc(O)c(O)c1</smiles>

b)

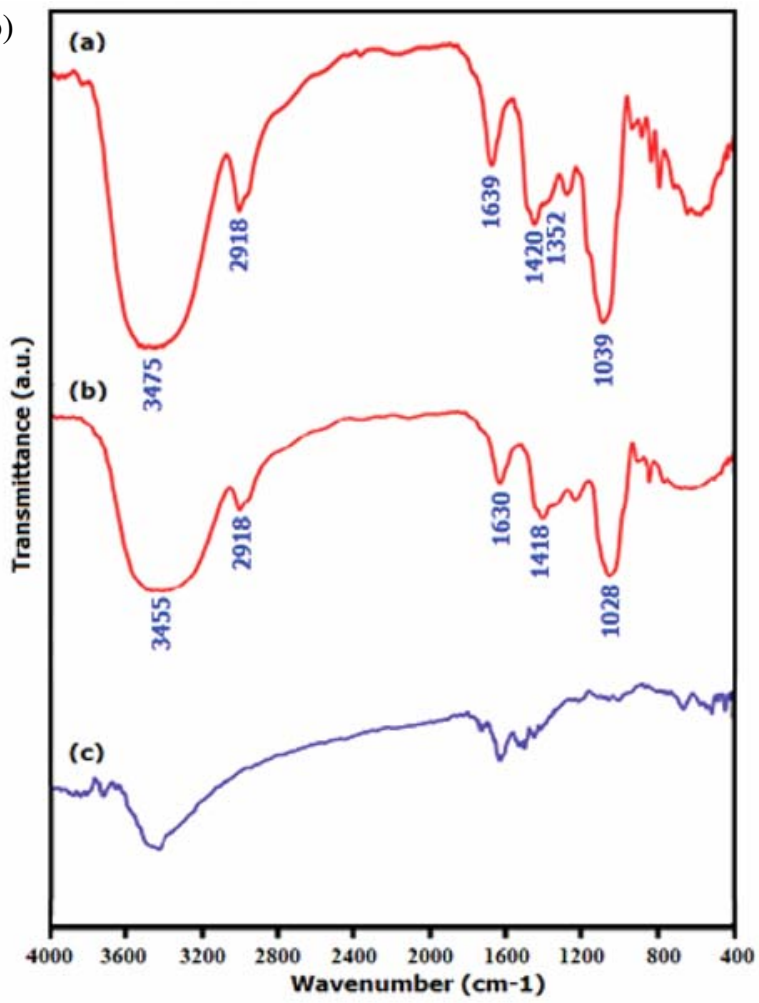

Figure 9. (A) The structure of some of phytochemicals present in Date fruits: (a)-(c) Phenolic acids, (d) a Flavonoid, (e) a Procyanidin, (f) a Sterol, (g) a Carotenoid. (B) FT-IR spectra of: (a) Date palm fruit extract, (b) Ag NPs capped with Date fruit extract solution and (c) Ag NPs after washing with deionized water 
$\mathrm{C}-\mathrm{OH}$ stretching bands, corresponding to a number of bands at 3475,1639 , and $1039 \mathrm{~cm}^{-1}$, respectively. The absorption bands at 2918,1420, and $1352 \mathrm{~cm}^{-1}$ are related to the $\mathrm{C}-\mathrm{H}$ stretching bands in Date fruit. As shown in Figure 9(B), (spectrum b), after the reduction of Ag$\mathrm{NO}_{3}$ the decreases in intensity of bands at 3450 and 1039 $\mathrm{cm}^{-1}$ and redshift of these bands signify the involvement of the $\mathrm{OH}$ groups in the reduction process. On the hand the shift of the band from $1639 \mathrm{~cm}^{-1}$ to $1630 \mathrm{~cm}^{-1}$ is attributed to the binding of $\mathrm{C}=\mathrm{O}$ groups with $\mathrm{Ag}$ NPs. On the base of FT-IR analysis, it can be stated that the hydroxyl, carboxyl and carbonyl functional groups present in carbohydrates, flavonoids, tannins and phenolic acids of Date fruit extract may be accountable for the reduction of the $\mathrm{Ag}^{+}$ions and stabilization of $\mathrm{Ag}$ NPs. In an experiment, the Ag NPs capped with Date extract were washed with deionized water for three times and the FT-IR spectrum of the dried precipitate was again taken for the purity of the sample. As can be clearly seen in Figure 9(B), (spectrum c), the intensity of the characteristic bands of biomolecules markedly decreases after washing the product, confirming the removal of biomolecules on the surface of Ag NPs.

From the FTIR analysis and previously reported mechanisms, ${ }^{68-70}$ it can be stated that the hydroxyl and carbonyl groups present in carbohydrates, flavonoids, procyanidin and phenolic compounds are powerful reducing agents and they may be accountable for the bioreduction of $\mathrm{Ag}^{+}$ions leading to $\mathrm{Ag}^{0}$ nanoparticle synthesis. FTIR study confirms that the carbonyl groups of biomolecules have a strong ability to bind metal ions and they may be encapsulated around the Ag NPs forming a protective coat-like membrane to avoid the agglomeration and thus results in nanoparticle stabilization in the medium. Thus, the Date fruit extract components act as bioreductants and surfactants too. The plausible mechanism of the formation of Ag NPs by using a Flavonoid biomolecule as a typical reducing agent is shown in Figure 10. In this pursuit, proteins and all secondary metabolites of extract play a critical role in both reducing and capping mechanism for nanoparticle formation.

\section{7. Antibacterial Activity of Ag Nanoparticles}

The antibacterial activity of Ag NPs were analyzed against five bacteria: Bacillus cereus, Staphylococcus aureus, Staphylococcus epidermidis, Klebsiella pneumonia, and Escherichia coli by disk diffusion method. The results of the antibacterial activity of silver nanoparticles were showed in Figure 11. The Figure shows that Ag NPs have good antibacterial activity; bacteria cells have been killed at the concentration of $30 \mu \mathrm{g} / \mathrm{ml}$. Table 1 represented the inhibition zone of these bacteria. Highest activity of $\mathrm{Ag}$ NPs was obtained against epidermidis, while lowest activity were observed against B. cereus and E. coli. Biosynthesized Ag NPs exhibit more antimicrobial activity on

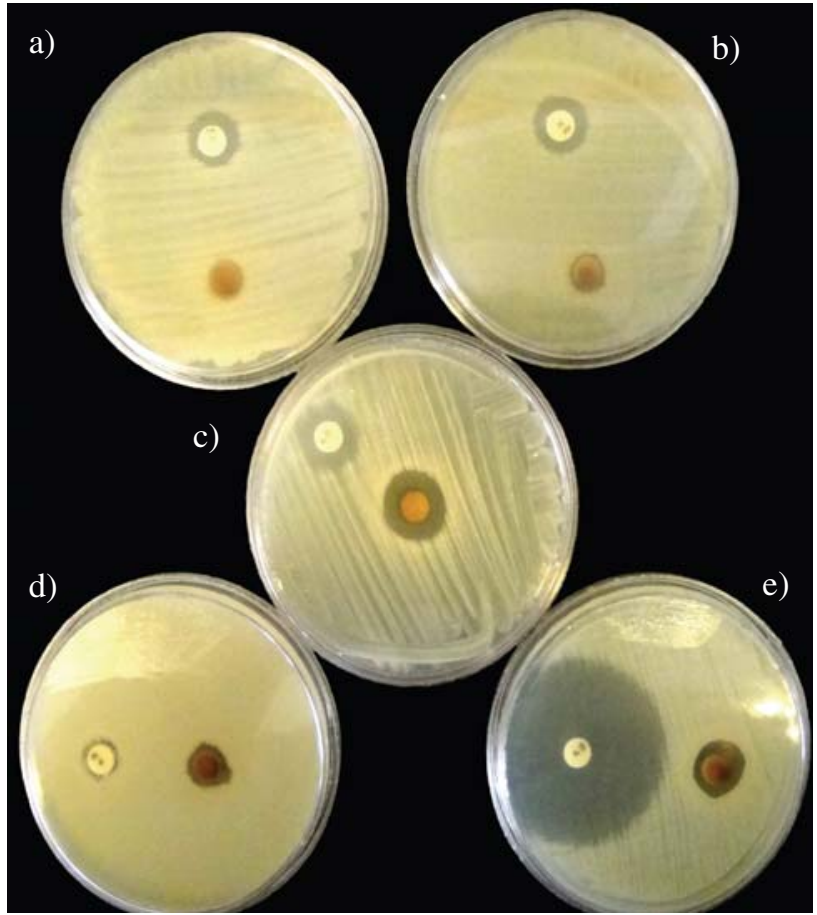

Figure 11. Images of antibacterial activities of Discs $30 \mu \mathrm{g} / \mathrm{mL} \mathrm{Ag}$ NPs on (a) E. Coli, (b) K. Pneumonia, (c) S. Epidermidis, (d) B. Cereus. (e) S. Aureus.

\section{A Flavonoid biomolecule present in Date fruit extract as a typical reducing agent}<smiles>O=c1c(O)c(-c2ccc(O)c(O)c2)oc2cc(O)cc(O)c12</smiles>

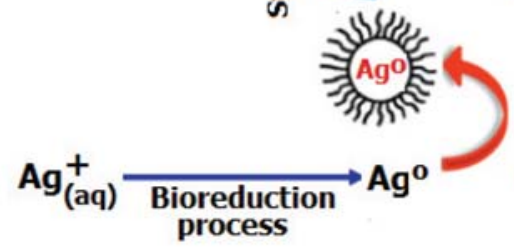

process

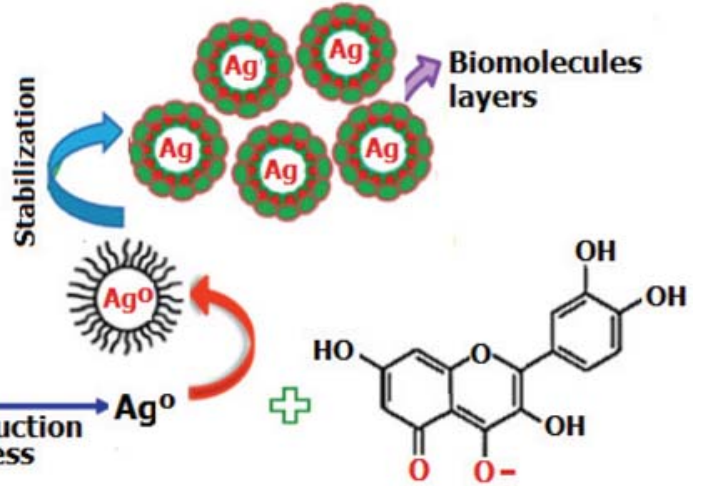

Figure 10. The plausible mechanism of the formation of Ag NPs using Date fruit extract 
Table 1. Average of inhibition zones synthesized silver nanoparticles with Date fruit extract.

\begin{tabular}{lllcc}
\hline \multirow{2}{*}{ Entry } & Bacteria & \multirow{2}{*}{ Type } & \multicolumn{2}{c}{ Inhibition zone diameter (mm) } \\
& & & Silver nanoparticle & Disc standard \\
\hline 1 & E. Coli & Gram-negative & 11 & 13 \\
2 & K. Pneumonia & Gram-negative & 17 & 13 \\
3 & S. Epidermidis & Gram-positive & 12 & 14 \\
4 & B. Cereus & Gram-positive & 13 & 11 \\
5 & S. Aureus & Gram-positive & & 41 \\
\hline
\end{tabular}

gram-positive microorganism than gram-negative. The potential antimicrobial activities showed by Ag NPs have made them encouraging candidates as novel generation antimicrobials.

\section{8. Catalytic Activity of Ag Nanoparticles}

To evaluate the catalytic activity of the Ag NPs prepared in this work by using Date fruit extract, the reduction of 4-nitrophenol (4-NP) and 4-nitroaniline (4-NA) in aqueous solution by excess $\mathrm{NaBH}_{4}$ was used as the model systems. The catalytic process was monitored by UV-Vis spectroscopy as shown in Figure 12. From Figure 12(a), it was seen that an absorption peak of 4-NP undergoes a red shift from 317 to $400 \mathrm{~nm}$ immediately upon the addition of aqueous solution of $\mathrm{NaBH}_{4}$, corresponding to a significant change in solution color from light yellow to yellowgreen due to formation of 4-nitrophenolate ion. In the absence of Ag NPs catalyst $(0.5 \mathrm{mg})$, the absorption peak at $400 \mathrm{~nm}$ remained unaltered for a long duration, indicating that the $\mathrm{NaBH}_{4}$ itself cannot reduce 4-nitrophenolate ion without a catalyst. In the presence of Ag NPs catalyst and $\mathrm{NaBH}_{4}$ the 4-NP was reduced, and the intensity of the absorption peak at $400 \mathrm{~nm}$ decreased gradually with time and after about $24 \mathrm{~min}$ it fully disappeared (Figure 12(a)). In the meantime, a new absorption peak appeared at about $295 \mathrm{~nm}$ and increased progressively in intensity. This new peak is attributed to the typical absorption of 4-aminophenol (4-AP). This result suggests that the catalytic reduction of 4-NP exclusively yielded 4-AP, without any other side products. In the reduction process, the overall concentration of $\mathrm{NaBH}_{4}$ was $10 \mathrm{mM}$ and 4-NP was $0.1 \mathrm{mM}$. Considering the much higher concentration of $\mathrm{NaBH}_{4}$ compared to that of 4-NP, it is reasonable to assume that the concentration of $\mathrm{BH}_{4}^{-}$remains constant during the reaction. In this context, pseudo-first-order kinetics could be used to evaluate the kinetic reaction rate of the current catalytic reaction, together with the UV-Vis absorption data in Figure 12(a). The absorbance of 4-NP is proportional to its concentration in solution; the absorbance at time $t\left(A_{t}\right)$ and time $t=0\left(A_{0}\right)$ are equivalent to the concentration at time $t\left(\mathrm{C}_{\mathrm{t}}\right)$ and time $\mathrm{t}=0\left(\mathrm{C}_{0}\right)$. The rate constant $(\mathrm{k})$ could be determined from the linear plot of $\ln \left(\mathrm{C}_{\mathrm{t}} / \mathrm{C}_{0}\right)$ versus reduction time in minutes. As expected, a good linear correlation of $\ln \left(\mathrm{C}_{t} / \mathrm{C}_{0}\right)$ versus time was obtained as shown in the inset of Figure 12(a), whereby a kinetic reac- tion rate constant $\mathrm{k}$ is estimated to be $1.34 \times 10^{-1} \mathrm{~min}^{-1}$. Figure 12(b) shows the UV-Vis absorption spectra of the reduction of 4-nitroaniline by $\mathrm{NaBH}_{4}$ at various reaction times in the presence of $\mathrm{Ag}$ NPs. The observed peak at $385 \mathrm{~nm}$ for the 4-nitroaniline shows a gradual decrease in intensity with time and a new peak appeared at $295 \mathrm{~nm}$ indicating the formation of p-phenylenediamine (1,4-PD). As shown in Figure 12(b), it took 24 min for the complete reduction of 4-NA in the presence of Ag NPs $(0.5 \mathrm{mg})$.
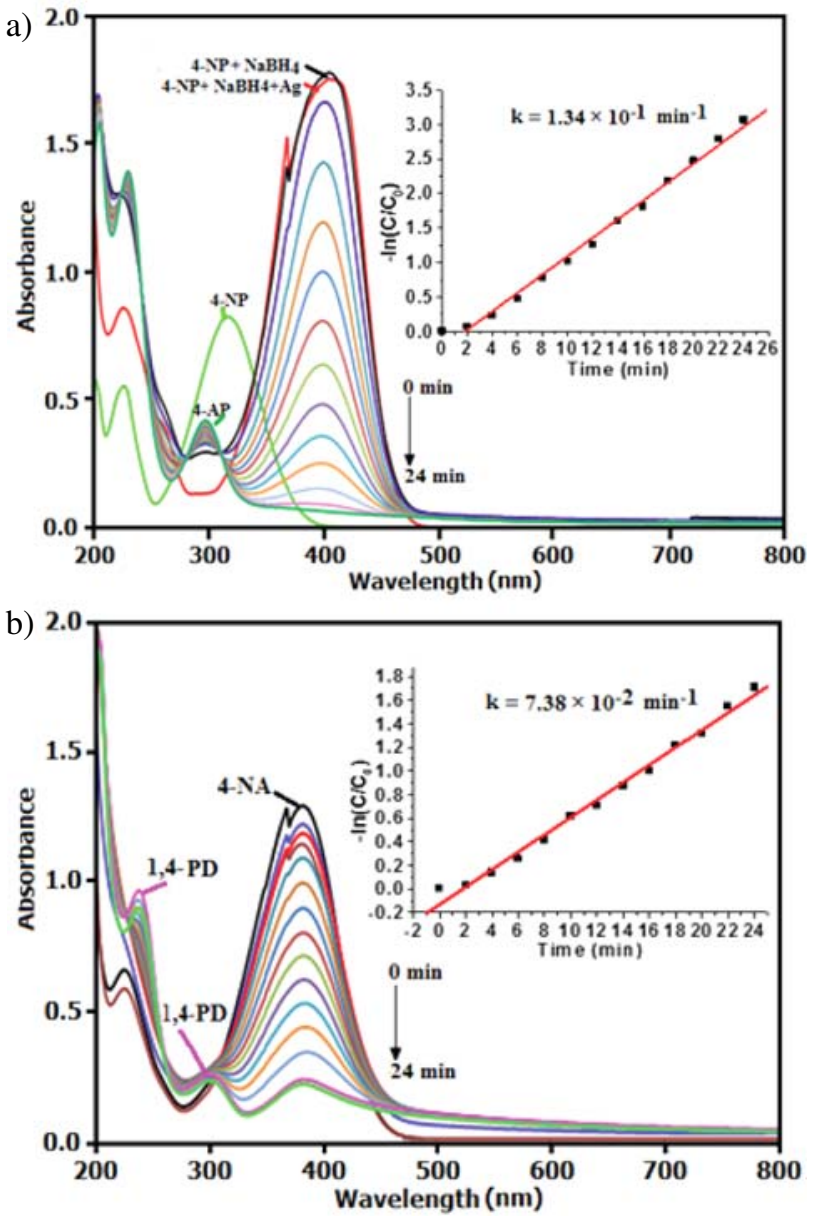

Figure 12. UV-Vis spectra of (a) $0.1 \mathrm{mM}$ 4-nitrophenol (4-NP) with $10 \mathrm{mM} \mathrm{NaBH} 4$ and (b) $0.1 \mathrm{mM}$ 4-nitroaniline (4-NA) with 10 $\mathrm{mM} \mathrm{NaBH} 4$ in the presence of $\mathrm{Ag} \mathrm{NPs}$ as catalyst. The insets show the plots of $\ln \left(\mathrm{C}_{\mathrm{t}} / \mathrm{C}_{0}\right)$ against the reaction time for pseudo-first-order reduction kinetics of 4-NP and 4-NA in the presence of excess $\mathrm{NaBH}_{4}(10 \mathrm{mM})$ in aqueous solutions. 



Fig. 13. (a) XRD pattern and (b) SEM image of the recovered Ag NPs after the fourth cycle.

The corresponding $\mathrm{k}$ value was $7.38 \times 10^{-2} \mathrm{~min}^{-1}$ (see the inset in Figure 12(b)). The results indicated that Ag NPs exhibited considerably high activity for the reduction of nitroarenes with $\mathrm{NaBH}_{4}$ as the hydrogen donor.

The reusability of catalysts is a very important parameter to assess the catalyst practicability. Therefore, the recovery and reusability of the $\mathrm{Ag}$ catalyst was investigated for the reduction of 4-NP under the present reaction conditions. After the completion of reaction, Ag NPs were separated from the reaction mixture by centrifugation. The catalyst was washed with water and ethanol several times, dried and employed for the next reaction. The activity of the four consecutive runs $(98,98,97$ and $95 \%)$ revealed the practical recyclability of the applied catalyst.
No significant loss in activity was observed for up to four catalytic cycles, thereby indicating that the as-prepared catalyst is stable and efficient in the reduction of nitrocompounds. As shown in Fig. 13(a) and (b), XRD and SEM image of the recycled catalyst did not show significant change after the fourth run in comparison with the fresh catalyst (see Figures 4 and 5). This observation confirmed that the Ag NPs are stable under the reaction conditions and are not affected by the reactants.

Moreover, we have compared the obtained results in the reduction of 4-NP with $\mathrm{NaBH}_{4}$ catalyzed by Ag NPs prepared in this work with some reported catalysts in the literature (Table 2). It is clear that with respect to the reaction conditions and/or reaction times, the present method

Table 2. Comparison of the result obtained for the reduction of 4-NP in the present work with those obtained by some reported catalysts.

\begin{tabular}{|c|c|c|c|c|}
\hline Entry & Catalyst & Conditions & Time & Ref. \\
\hline 1 & Ni-PVA/SBA-15 & $\mathrm{H}_{2} \mathrm{O}, \mathrm{NaBH}_{4}$, r.t. & $85 \min$ & [71] \\
\hline 2 & Hierarchical $\mathrm{Au} / \mathrm{CuO}$ NPs & $\mathrm{H}_{2} \mathrm{O}, \mathrm{NaBH}_{4}$, r.t & $80 \mathrm{~min}$ & [72] \\
\hline 3 & $\mathrm{Cu}$ NPs & $\mathrm{THF} / \mathrm{H}_{2} \mathrm{O}, \mathrm{NaBH}_{4}, 50^{\circ} \mathrm{C}$ & $2 \mathrm{~h}$ & [73] \\
\hline 4 & $\mathrm{PdCu} /$ graphene & $\mathrm{EtOH} / \mathrm{H}_{2} \mathrm{O}, \mathrm{NaBH}_{4}, 50^{\circ} \mathrm{C}$ & $1.5 \mathrm{~h}$ & [74] \\
\hline 5 & $\mathrm{Au}-\mathrm{GO}$ & $\mathrm{H}_{2} \mathrm{O}, \mathrm{NaBH}_{4}$, r.t. & $30 \min$ & [75] \\
\hline 6 & $\mathrm{CoFe}_{2} \mathrm{O}_{4} \mathrm{NPs}$ & $\mathrm{H}_{2} \mathrm{O}, \mathrm{NaBH}_{4}$, r.t. & $50 \mathrm{~min}$ & [76] \\
\hline 7 & $\mathrm{FeNi}_{2}$ nano-alloy & $\mathrm{H}_{2}^{2} \mathrm{O}, \mathrm{NaBH}_{4}$, r.t & $60 \mathrm{~min}$ & [77] \\
\hline 8 & $\mathrm{NiCo}_{2}$ nano-alloy & $\mathrm{H}_{2} \mathrm{O}, \mathrm{NaBH}_{4}$, r.t. & $30 \mathrm{~min}$ & [78] \\
\hline 9 & $\mathrm{CdS} / \mathrm{GO}$ & $\mathrm{H}_{2} \mathrm{O}, \mathrm{NaBH}_{4}$, r.t. & $30 \mathrm{~min}$ & [79] \\
\hline 10 & dumbbell-like CuO NPs & $\mathrm{H}_{2} \mathrm{O}, \mathrm{NaBH}_{4}$, r.t. & $32 \min$ & {$[80]$} \\
\hline 11 & Ni NPs & $\mathrm{H}_{2} \mathrm{O}, \mathrm{NaBH}_{4}$, r.t. & $16 \min$ & [81] \\
\hline 12 & $\mathrm{CuFe}_{2} \mathrm{O}_{4} \mathrm{NPs}$ & $\mathrm{H}_{2} \mathrm{O}, \mathrm{NaBH}_{4}$, r.t. & $14 \min$ & [82] \\
\hline 13 & $\mathrm{Au} \mathrm{NPs}^{+}$ & $\mathrm{H}_{2} \mathrm{O}, \mathrm{NaBH}_{4}$, r.t. & $4 \min$ & [83] \\
\hline 14 & $\mathrm{Pd} / \mathrm{RGO} / \mathrm{Fe}_{3} \mathrm{O}_{4} \mathrm{NPs}$ & $\mathrm{H}_{2} \mathrm{O}, \mathrm{NaBH}_{4}$, r.t. & $1 \mathrm{~min}$ & [84] \\
\hline 15 & $\mathrm{Cu} / \mathrm{Fe}_{3} \mathrm{O}_{4} \mathrm{NPs}^{+}$ & $\mathrm{H}_{2} \mathrm{O}, \mathrm{NaBH}_{4}$, r.t. & $55 \mathrm{sec}$ & [85] \\
\hline 16 & $\mathrm{Cu}$ NPs/perlite & $\mathrm{H}_{2} \mathrm{O}, \mathrm{NaBH}_{4}$, r.t. & $2.5 \mathrm{~min}$ & [86] \\
\hline 17 & Ag NPs & $\mathrm{H}_{2} \mathrm{O}, \mathrm{NaBH}_{4}$, r.t. & $24 \min$ & This work \\
\hline
\end{tabular}


is more suitable and/or superior (Table 2, entries 1-10). It is clear that reaction in the presence of most reported catalysts required longer reaction times. However, compared with some these reports, the present catalyst also presented close or lower catalytic activity for the reduction of 4-NP (Table 2, entries 11-16). Furthermore, compared with the other catalysts, the Ag NPs can be easily prepared using Date fruit extract without the use of harsh, toxic and expensive chemicals which is very important in practical applications.

\section{Conclusions}

In the present work, Date fruit extract was used as an effective reducing as well as capping agent for the biosynthesis Ag NPs in aqueous solution. The synthesis of Ag NPs was affected by the variation in reaction conditions such as time, temperature, concentration of extract and silver solution and $\mathrm{pH}$. The synthesized $\mathrm{Ag}$ NPs were spherical, 25-60 $\mathrm{nm}$ in size, crystal in nature and showed absorption spectrum at $\sim 400-420 \mathrm{~nm}$. The formed Ag NP$\mathrm{s}$ were quite stable, showed good antimicrobial activity and were utilized as a catalyst for the reduction of several aromatic nitro-compounds into their corresponding amino derivatives. Thus Date extract can be effectively used for the synthesis of Ag NPs. Further experiments for the synthesis other metal nanoparticles such as $\mathrm{Au}, \mathrm{Pd}$, and $\mathrm{Cu}$, using Date fruit extract are in progress in our laboratory. Synthesis of metallic nanoparticles using green resources like Date fruit extract is a challenging alternative to chemical synthesis, since this novel green synthesis is cost effective, pollutant free and eco-friendly synthetic route.

\section{Acknowledgements}

The authors gratefully acknowledge the Lorestan University Research Council and Iran Nanotechnology Initiative Council (INIC) for their financial supports.

\section{References}

1. K. Nishioka, T. Sueto, N. Saito, Appl. Surf. Sci. 2009, 255, 9504-9507. https://doi.org/10.1016/j.apsusc.2009.07.079

2. Y. W. C. Cao, R. C. Jin, C. A. Mirkin, Sci. 2002, 297, 15361540. https://doi.org/10.1126/science.297.5586.1536

3. V. K. Vidhu, D. Philip, Micron 2014, 56, 54-62. https://doi.org/10.1016/j.micron.2013.10.006

4. C. J. Kirubaharan, D. Kalpana, Y. S. Lee, A. R. Kim, D. J. Yoo, K. S. Nahm, G. G. Kumar, Ind. Eng. Chem. Res., 2012, 51, 7441-7446. https://doi.org/10.1021/ie3003232

5. M. Rahban, A. Divsalar, A. A. Saboury, A. Golestani, J. Am. Phys. Chem. C 2010, 114, 5798-5803.
6. M. Miranzadeh, M. Z. Kassaee, L. Sadeghi, M, Sadroddini, M. Razzaghi-Kashani, N. Khoramabadi, Nanochem. Res. 2016, 1, 1-8.

7. M. Ohtaki, N. Toshima, Chem. Lett. 1990, 4, 489-492. https://doi.org/10.1246/cl.1990.489

8. Y. Mizukoshi, K. Okisu, Y. Maeda, T. A. Yamamoto, R. Oshima, Y. Nagata, J. Am. Phys. Chem. B 1997, 101, 7033-7037. https://doi.org/10.1021/jp9638090

9. M. Khademalrasool, M. Farbod, J. Nanostruct. 2015, 5, 415-422

10. S. Darvishi, S. M. Borghei, S. A. Hashemizadeh, J. Nanostruct. 2012, 2, 501-504.

11. B. J. Wiley, Y. Sun, Y. Xia, Acc. Chem. Res. 2007, 40, 10671076. https://doi.org/10.1021/ar7000974

12. H. Ahmad, K. Rajagopal, A.H. Shah, Int. J. Nano Dimens. 2016, 7, 97-108.

13. T. Klaus, R. Joerger, E. Olsson, C. G. Granqvist, Proc. Natl. Acad. Sci. 1999, 96, 13611-13614. https://doi.org/10.1073/pnas.96.24.13611

14. Y. Roh, R. J. Lauf, A. D. McMillan, C. Zhang, C. J. Rawn, J. Bai, T. J. Phelps, Solid State Commun. 2001, 118, 529-534. https://doi.org/10.1016/S0038-1098(01)00146-6

15. B. Nair, T. Pradeep, Cryst. Growth. Des. 2002, 2, 293-298. https://doi.org/10.1021/cg0255164

16. P. Yong, N. A. Rowson, J. P. G. Farr, I. R. Harris, L. E. Macaskie, Biotechnol. Bioeng. 2002, 80, 369-379. https://doi.org/10.1002/bit.10369

17. M. I. Husseiny, M. A. El-Aziz, Y. Badr, M. A. Mahmoud, Spectrochim. Acta A 2007, 67, 1003-1006. https://doi.org/10.1016/j.saa.2006.09.028

18. P. Mukherjee, A. Ahmad, D. Mandal, S. Senapati, S. R. Sainkar, M. I. Khan, R. Parishcha, P. V. Ajaykumar, M. Alam, R. Kumar, M. Sastry, Nano. Lett. 2001, 1, 515-519. https://doi.org/10.1021/n10155274

19. P. Mukherjee, A. Ahmad, D. Mandal, S. Senapati, S. R. Sainkar, M. I. Khan, R. Ramani, R. Parischa, P. A. Ajaykumar, M. Alam, M. Sastry, R. Kumar, Angew. Chem. Int. Ed. 2001, 40, 3585-3588.

https://doi.org/10.1002/1521-3773(20011001)40:19<3585: :AID-ANIE3585>3.0.CO;2-K

20. A. Ahmad, S. Senapati, M. I. Khan, R. Kumar, J. Biomed. Nanotechnol. 2005, 1, 47-53. https://doi.org/10.1166/jbn.2005.012

21. A. Ahmad, S. Senapati, M. I. Khan, R. Kumar, R. Ramani, V. Srinivas, M. Sastry, Nanotechnology 2003, 14, 824-828. https://doi.org/10.1088/0957-4484/14/7/323

22. A. Ahmad, S. Senapati, M. I. Khan, R. Kumar, M. Sastry, Langmuir 2003, 19, 3550-3553. https://doi.org/10.1021/la0267721

23. M. Sastry, A. Ahmad, M. I. Khan, R. Kumar, Curr. Sci. 2003, 85, 162-170.

24. M. Kowshik, S. Arhtaputre, S. Kharrazi, W. Vogel, J. Urban, S. K. Kulkarni, K. M. Paknikar, Nanotechnology 2003, 14, 95-100. https://doi.org/10.1088/0957-4484/14/1/321

25. W. Shenton, T. Douglas, M. Young, G. Stubbs, S. Mann, $A d v$. Mater. 1999, 11, 253-256. 
https://doi.org/10.1002/(SICI)1521-4095(199903)11:3<253: :AID-ADMA253>3.0.CO;2-7

26. S. W. Lee, C. Mao, C. Flynn, A. M. Belcher, Sci. 2002, 296, 892-895. https://doi.org/10.1126/science.1068054

27. A. Merzlyak, S. W. Lee, Curr. Opin. Chem. Biol. 2006, 10, 246-252. https://doi.org/10.1016/j.cbpa.2006.04.008

28. S. M. Ali, V. Anuradha, N. Yogananth, R. Rajathilagam, A. Chanthuru, S. M. Marzook, Int. J. Nano Dimens. 2015, 6, 197-204.

29. N. T. M. Tho, T. N. M. An, M. D. Tri, T. V. M. Sreekanth, J.S. Lee, P. C. Nagajyothi, K. D. Lee, Acta Chim. Slov. 2013, 60, 673-678.

30. P. P. Vijaya., M. S. Ali, R. S. Saranya, N. Yogananth, V. Anuratha, P. K. Parveen, Int. J. Nano Dimens. 2013, 3, 255-262.

31. P. Prakash, P. Gnanaprakasam, R. Emmanuel, S. Arokiyaraj, M. Saravanan, Colloids Surf. B 2013, 108, 255-259. https://doi.org/10.1016/j.colsurfb.2013.03.017

32. R. R. R. Kannan, R. Arumugam, D. Ramya, K. Manivannan, P. Anantharaman, Appl. Nanosci. 2013, 3, 229-233. https://doi.org/10.1007/s13204-012-0125-5

33. A. Rostami-Vartooni, M. Nasrollahzadeh, M. Alizadeh, $J$. Colloid Interface Sci. 2016, 470, 268-275. https://doi.org/10.1016/j.jcis.2016.02.060

34. B. Sadeghi, Int. J. Nano Dimens. 2014, 5, 575-581.

35. A. Rostami-Vartooni, M. Nasrollahzadeh, M. Alizadeh, J. Alloys Compd. 2016, 680, 309-314. https://doi.org/10.1016/j.jallcom.2016.04.008

36. K. M. Ponvel, T. Narayanaraja, J. Prabakaran, Int. J. Nano Dimens. 2015, 6, 339-349.

37. H. R. Rajabi, H. Deris, H. S. Faraji, Nanochem. Res. 2016, 1, 177-182.

38. D. M. Ali, N. Thajuddin, K. Jeganathan, M. Gunasekhran, Colloids Surf. B 2011, 85, 360-365. https://doi.org/10.1016/j.colsurfb.2011.03.009

39. A. R. Allafchian, S. Z. Mirahmadi-Zare, S. A. H. Jalali, S. S. Hashemi, M. R. Vahabi, J. Nanostruct Chem. 2016, 6, 129135.

40. S. Sedaghat, A. Esmaeili-Agbolag, S. bagheriyan, J. Nanostruct Chem. 2016, 6, 25-27. https://doi.org/10.1007/s40097-015-0176-8

41. D. Philip, C. Unni, S. A. Aromal, V. K. Vidhu, Spectrochim. Acta A 2011, 78, 899-904.

https://doi.org/10.1016/j.saa.2010.12.060

42. D. Phillip, Spectrochim. Acta A 2011, 78, 327-331. https://doi.org/10.1016/j.saa.2010.10.015

43. K. S. Prasad, D. Pathak, A. Patel, P. Dalwadi, R. Prasad, P. Patel, K. Selvaraj, J. Afr. Biotechnol. 2011, 10, 8122-8130. https://doi.org/10.5897/AJB11.394

44. M. L. Rao, N. Savithramma, J. Pharm. Sci. Res. 2011, 3, 1117-1121.

45. K. Satyavani, T. Ramanathan, S. Gurudeekan, Dig. J. Nanomater. Biostruct. 2011, 6, 1019-1024.

46. T. J. I. Edison, M. G. Sethuraman, Process. Biochem. 2012, 47, 1351-1357. https://doi.org/10.1016/j.procbio.2012.04.025

47. M. Ramar, B. Manikandan, P. N. Marimuthu, T. Raman, A.
Mahalingam, P. Subramanian, S. Karthick, A. Munusamy, Spectrochim. Acta A 2015, 140, 223-228.

https://doi.org/10.1016/j.saa.2014.12.060

48. S. Singha, J. P. Saikia, A. K. Buragohain, Colloids Surf. B 2013, 102, 83-85.

https://doi.org/10.1016/j.colsurfb.2012.08.012

49. M. Umadevi, M. R. Bindhu, V. Sathe, J. Mater. Sci. Technol. 2013, 29, 317-322.

https://doi.org/10.1016/j.jmst.2013.02.002

50. R. S. R. Isaac, G. Sakthivel, C. Murthy, J. Nanotech. 2013, $13,1-6$.

51. M. Ghaffari-Moghaddam, R. Hadi-Dabanlou, J. Ind. Eng. Chem. 2014, 20, 739-744.

https://doi.org/10.1016/j.jiec.2013.09.005

52. P. S. Ramesh, T. Kokila, D. Geetha, Spectrochim. Acta A 2015, 142, 339-343. https://doi.org/10.1016/j.saa.2015.01.062

53. Y. Gao, Q. Huang, Q. Su, R. Liu, Spect. Lett. 2014, 47, 790795. https://doi.org/10.1080/00387010.2013.848898

54. M. Chandrasekaran, A. H. Bahkali, Saudi J. Biol. Sci. 2013, 20, 105-120. https://doi.org/10.1016/j.sjbs.2012.12.004

55. J. Wang, C. M. Rosell, C. B. Barber, Food Chem. 2002, 79, 221-226. https://doi.org/10.1016/S0308-8146(02)00135-8

56. A. Paraskevopoulou, D. Boskou, V. Kiosseoglou, Food Chem. 2005, 90, 627-634. https://doi.org/10.1016/j.foodchem.2004.04.023

57. M. Abdelhak, E. Guendez, K. Eugene, K. Panagiotis, Food Chem. 2005, 89, 411-420.

https://doi.org/10.1016/j.foodchem.2004.02.051

58. P. K. Vayalil, J. Agric. Food. Chem. 2002, 50, 610-617. https://doi.org/10.1021/jf010716t

59. F. Bilgari, A. F. M. Alkarkhi, A. M. Easa, Food Chem. 2008, 107, 1636-1641. https://doi.org/10.1016/j.foodchem.2007.10.033

60. M. S. Baliga, B. R. V. Baliga, S. M. Kandathil, H. P. Bhat, P. K. Vayalil, Food. Res. Int. 2011, 44, 1812-1822. https://doi.org/10.1016/j.foodres.2010.07.004

61. A. M. Fayaz, K. Balaji, P. T. Kalaichelvan, R. Venkatesan, Colloids Surf. B 2009, 74, 123-126. https://doi.org/10.1016/j.colsurfb.2009.07.002

62. J. Park, J. Joo, S. G. Kwon, Y. Jang, T. Hyeon, Angew. Chem. Inter. Ed. 2007, 46, 4630-4660.

63. S. M. Roopan, G. Madhumitha, A. A. Rahuman, C. Kamaraj, A. Bharathi, T. V. Surendra, Ind. Crop. Prod. 2013, 43, 631635. https://doi.org/10.1016/j.indcrop.2012.08.013

64. H. M. M. Ibrahim, J. Rad. Res. Appl. Sci. 2015, 8, 265-275.

65. D. A. Kumar, V. Palanichamy, S. M. Roopan, Spectrochim. Acta A 2014, 127, 168-171. https://doi.org/10.1016/j.saa.2014.02.058

66. R. Kumar, S. M. Roopan, A. Prabhakarn, V. G. Khanna, S. Chakroborty, Spectrochim. Acta A 2012, 90, 173-176. https://doi.org/10.1016/j.saa.2012.01.029

67. S. Naraginti, A. Sivakumar, Spectrochim. Acta A 2014, 128, 357-362. https://doi.org/10.1016/j.saa.2014.02.083

68. M. Nasrollahzadeh, S. M. Sajadi, A. Rostami-Vartooni, M. Khalaj, J. Mol. Catal. A: Chem. 2015, 396, 31-39. 
https://doi.org/10.1016/j.molcata.2014.09.029

69. M. Nasrollahzadeh, S. M. Sajadi, A. Rostami-Vartooni, M. Alizadeh, M. Bagherzadeh J. Colloid Interface Sci. 2016, 466, 360-368. https://doi.org/10.1016/j.jcis.2015.12.036

70. A. Rostami-Vartooni, M. Nasrollahzadeh, M. SalavatiNiasari, M. Atarod, J. Alloys Compd. 2016, 689, 15-20. https://doi.org/10.1016/j.jallcom.2016.07.253

71. R. J. Kalbasi, A. A. Nourbakhsh, F. Babaknezhad, Catal. Commun. 2011, 12, 955-960. https://doi.org/10.1016/j.catcom.2011.02.019

72. S. Y. Gao, X. X. Jia, Z. D. Li, Y. L. Chen, J. Nanopart. Res. 2012, 14, 1-11.

73. Z. Duan, G. Ma, W. Zhang, Bull. Korean Chem. Soc. 2012 , 33, 4003-4006. https://doi.org/10.5012/bkcs.2012.33.12.4003

74. A. K. Shil, D. Sharma, N. R. Guha, P. Das, Tetrahedron Lett. 2012, 53, 4858-4861. https://doi.org/10.1016/j.tetlet.2012.06.132

75. Y. Choi, H. S. Bae, E. Seo, S. Jang, K. H. Park, B. S. Kim, J. Mater. Chem. 2011, 21, 15431-15436. https://doi.org/10.1039/c1jm12477c

76. M. Nasrollahzadeh, M. Bagherzadeh, H. Karimi, J. Colloid Interface Sci. 2016, 465, 271-278. https://doi.org/10.1016/j.jcis.2015.11.074

77. K. L. Wu, R. Yu, X. W. Wei, Cryst. Eng. Commun. 2012, 14, 7626-7632. https://doi.org/10.1039/c2ce25457c
78. K. L. Wu, X. W. Wei, X. M. Zhou, D. H. Wu, X. W. Liu, Y. Ye, Q. Wang, J. Phys. Chem. C 2011, 115, 16268-16274. https://doi.org/10.1021/jp201660w

79. S. Liu, Z. Chen, N. Zhang, Z. R. Tang, Y. J. Xu, J. Phys. Chem. C, 2013, 117, 8251-8261. https://doi.org/10.1021/jp400550t

80. W. Che, Y. Ni, Y. Zhang, Y. Ma, J. Phys. Chem. Solids 2015, 77, 1-7. https://doi.org/10.1016/j.jpcs.2014.09.006

81. D. Z. Jiang, J. Xie, D. Jiang, X. Wei, M. Chen, Cryst. Eng. Comm. 2013, 15, 560-569. https://doi.org/10.1039/C2CE26398J

82. J. Feng, L. Su, Y. Ma, C. Ren, Q. Guo, X. Chen, Chem. Eng. J. 2013, 221,16-24. https://doi.org/10.1016/j.cej.2013.02.009

83. Q. Cui, B. Xia, S. Mitzscherling, A. Masic, L. Li, M. Bargheer, H. Möhwald, Colloids Surf. A: Physicochem. Eng. Aspects 2015, 465, 20-25. https://doi.org/10.1016/j.colsurfa.2014.10.028

84. M. Atarod, M. Nasrollahzadeh, S. M. Sajadi, J. Colloid Interface Sci. 2016, 465, 249-258 https://doi.org/10.1016/j.jcis.2015.11.060

85. M. Nasrollahzadeh, M. Atarod, S. M. Sajadi, Appl. Surf. Sci. 2016, 364, 636-644. https://doi.org/10.1016/j.apsusc.2015.12.209

86. M. Nasrollahzadeh, S. M. Sajadi, Ceram. Int. 2015, 41, $14435-14439$.

https://doi.org/10.1016/j.ceramint.2015.07.079

\section{Povzetek}

V tem članku poročamo o sintezi sferičnih nanodelcev srebra (Ag NPs), ki smo jih sintetizirali s poceni, hitrim, enostavnim in okolju prijaznim pristopom. Za sintezo smo uporabili sadni izvleček datljeve palme kot naraven reducent in stabilizator. Produkte smo karakterizirali z UV-Vis spektroskopijo, rentgensko praškovno difrakcijo (XRD), infrardečo spektroskopijo (FT-IR), vrstično elektronsko mikroskopijo (FE-SEM), presevno elektronsko mikroskopijo (TEM), mikroskopijo na atomsko silo (AFM), energijsko disperzivno rentgensko spektroskopija (EDX) in meritvami zeta potenciala. Preučevali smo različne parametre reakcijskih pogojev kot so čas, množine reducenta in srebrovega nitrata, temperatura, pH. Optimalni reakcijski pogoji sinteze srebrovih nanodelcev (Ag NPs) so bili doseženi v primeru reakcije 10 $\mathrm{mM}$ raztopine srebrovega nitrata s sadnim izvlečkom datljeve palme pri $\mathrm{pH} 11$ in temperaturi do $55^{\circ} \mathrm{C}$ v 10 minutah. Elementarno in kristalinično naravo nanodelcev srebra (Ag NPS) smo potrdili z EDX in XRD analizama. SEM in TEM slike so pokazale, da so nanodelci srebra (Ag NPs) sferični, z velikostjo v območju od 25-60 nm. Na osnovi FT-IR analize, lahko rečemo, da so funkcionalne skupine prisotne v bioloških molekulah sadnega izvlečka datljevih palm odgovorne za redukcijo in stabilizacijo nanodelcev srebra (Ag NPs). Dokazali smo njihovo učinkovito antibakterijsko delovanje proti nekaterim patogenim bakterijam. Preučevali smo tudi katalitsko aktivnost nanodelcev srebra (Ag NPs) za hitro in učinkovito zmanjšanje strupenih nitro spojin $\mathrm{v}$ manj strupene amine $\mathrm{z}$ uporabo $\mathrm{NaBH}_{4}$ 